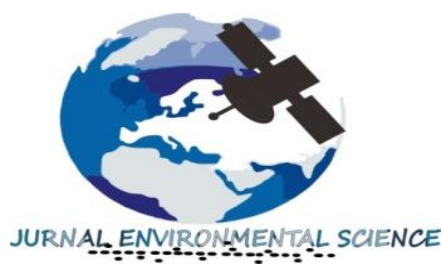

Jurnal EnvironmentaI Science

Volume 1 Nomor 1 Oktober 2018.

p-ISSN : 2654-4490 dan e-ISSN : 0000-0000

Homepage at : ojs.unm.ac.id/JES

E-mail:jes@unm.ac.id

\title{
Strategi Pedagang Kaki Lima Di Kawasan Kuliner Pantai Tak Berombak (Ptb) Kecamatan Turikale Kabupaten Maros
}

\author{
Bermanto Joyful Nimpa' \\ Jurusan Geografi, Fakultas Matematika Dan Ilmu Pengetahuan Alam, \\ Universitas Negeri Makassar, 2018, Indonesia
}

\begin{abstract}
This study aims to: (1) To identify and analyze the characteristics of street traders in Culinary Region Pantai Tak Berombak (PTB) Turikale District of Maros Regency. (2) To identify and analyze the factors that influence the development of enterprises in the Culinary Region Pantai Tak Berombak (PTB) Turikale District of Maros Regency. (3) To know and analyze the business development strategy carried out in order to develop optimally. Results showed (1) Characteristics of Street Vendors by age in Culinary Region Pantai Tak Berombak (PTB) Turikale District of Maros Regency dominated by the age group between 31-45 years. According to the education level is dominated by street vendors who had high school education. While the characteristics of street vendors by sex that most street vendors male. (2) Internal factors (knowledge and services) as well as external factors (location and personality) are factors that influence the development of enterprises Street Vendors Culinary Region Pantai Tak Berombak (PTB) Turikale District of Maros Regency. (3) Business development strategies that do street vendors can develop optimally, due to social capital, social networks and management.
\end{abstract}

Keywords: Street Vendors.

\begin{abstract}
ABSTRAK
Penelitian ini bertujuan: (1) Untuk mengetahui dan menganalisis karakteristik pedagang kaki lima di Kawasan Kuliner Pantai Tak Berombak (PTB) Kecamatan Turikale Kabupaten Maros. (2) Untuk mengetahui dan menganalisis faktor yang berpengaruh terhadap pengembangan usaha di Kawasan Kuliner Pantai Tak Berombak (PTB) Kecamatan Turikale Kabupaten Maros. (3) Untuk mengetahui dan menganalisis strategi pengembangan usaha yang dilakukan agar dapat berkembang secara maksimal. Hasil penelitian diperoleh (1) Karakteristik Pedagang Kaki Lima menurut umur di Kawasan Kuliner Pantai Tak Berombak (PTB) Kecamatan Turikale Kabupaten Maros didominasi oleh kelompok umur antara 31-45 tahun. Menurut jenjang pendidikannya didominasi oleh Pedagang Kaki Lima yang berpendidikan SLTA. Sedangkan karekteristik Pedagang Kaki Lima menurut jenis kelamin yang terbanyak Pedagang Kaki Lima laki-laki. (2) Faktor internal (pengetahuan dan pelayanan) serta faktor eksternal (lokasi dan kepribadian) merupakan faktor yang berpengaruh terhadap pengembangan usaha Pedagang Kaki Lima di Kawasan Kuliner Pantai Tak Berombak (PTB)
\end{abstract}


Kecamatan Turikale Kabupaten Maros. (3) Strategi pengembangan usaha yang dilakukan Pedagang Kaki Lima dapat berkembang secara maksimal, karena memiliki modal sosial, jaringan sosial dan manajemen.

Kata Kunci : Pedagang Kaki Lima

\section{PENDAHULUAN}

Perekonomian merupakan bagian yang tidak bisa dipisahkan dalam kehidupan manusia sehari-hari. Kebutuhan akan sandang dan pangan harus dipenuhi setiap harinya. Perekonomian suatu masyarakat juga memiliki peranan yang penting untuk mengukur kestabilan suatu bangsa dan negara. Tidak hanya itu, tingkat pertumbuhan dan pembangunan suatu negara juga dapat dilihat dari tingkat ekonomi masyarakatnya (Haryanto, 2011:15).

Alternatif usaha bagi tenaga kerja yang tidak terserap dalam usaha sektor formal adalah membuka usaha di sektor informal. Tenaga kerja yang berjumlah 91,86\% ini, yang terserap di sektor formal sebesar $30,51 \%$ dan sisanya sebesar 68,49\% terserap di Usaha Mikro/PKL. Ini membuktikan bahwa alternatif usaha yang ditempuh oleh tenaga kerja yang tidak terserap dalam usaha sektor formal adalah dengan membuka usaha di sektor informal. Kondisi ini tidak jauh berbeda dengan hasil penelitian ILO, di mana $35 \%$ penduduk Indonesia bekerja di sektor formal dan sisanya $65 \%$ bekerja di Usaha Mikro/PKL. Menurut Badan Penanaman Modal Asing, diperkirakan bahwa sekitar $70 \%$ modal domestik dan asing diinvestasikan di kota-kota besar di Indonesia, namun hanya menyerap sekitar 10-16\% tenaga kerja formal (Jumhur, 2015: 1).
Peran UMKM dalam perekonomian nasional dapat dilihat dari kedudukannya sebagai pemain utama dalam kegiatan ekonomi di berbagai sektor, penyedia lapangan kerja yang terbesar, pemain penting dalam pengembangan kegiatan ekonomi lokal dan pemberdayaan masyarakat, pencipta pasar baru dan sumber inovasi, dan sumbangannya dalam menjaga neraca pembayaran melalui kegiatan ekspor. PKL sebagai salah satu komponen utama dari Usaha Mikro yang terlibat dalam usaha sektor informal, menghadapi lingkungan yang masih kurang kondusif, sehingga menjadi faktor yang menghambat eksistensi dan perkembangan bisnisnya (Jumhur, 2015: 2).

Maros merupakan suatu kota yang terletak di jalur trans sulawesi memiliki tempat yang strategis dalam mengembangkan usaha ekonomi. Dengan posisi tersebut masyarakat Maros lebih dominan bermata pencaharian sebagai pedagang. Selain sebagai pedagang masyarakat Maros juga sudah mampu mengembangkan mata pencahariannya, seperti wiraswasta dan pegawai negeri. Keberagaman mata pencaharian tersebut membawa Kabupaten Maros semakin maju dalam sektor sosial dan ekonomi. Kemajuan tersebut dapat dilihat dari pembangunan ruko-ruko dan tenda-tenda untuk kegiatan jual-beli.

Masyarakat Maros yang bermata pencaharian sebagai pedagang dalam 
melaksanakan kegiatan jual-beli, mereka lebih memilih tempat yang strategis yaitu didekat jalur trans sulawesi, alasannya agar mudah dijangkau oleh para pembeli. Selain itu tempat yang telah disediakan oleh pemerintah daerah seperti pasar yang merupakan lembaga ekonomi.

Pasar menjadi tempat berkumpulnya orang dari berbagai lapisan masyarakat dan tempat untuk kegiatan memperjual belikan suatu barang dagangan untuk memenuhi kebutuhan hidupnya. Pasar merupakan salah satu lembaga yang paling penting dalam institusi ekonomi dan juga salah satu penggerak utama dinamika kehidupan ekonomi (Damsar, 2009:83).

Kemajuan kabupaten Maros di bidang ekonomi tidak saja dilihat dari pembangunan ruko-ruko disekitar kabupaten Maros saja, namun disamping itu kemajuan kabupaten Maros ditunjang dengan masyarakat desa yang semakin kreatif dalam membuka usahanya. Dewasa ini banyak masyarakat desa yang sudah mampu membuka usaha sendiri dalam bidang ekonomi yaitu dengan cara berdagang dan bergabung dengan PKL (Pedagang Kaki Lima).

Dengan tantangan hidup yang semakin berat, lowongan pekerjaan yang terbatas, rendahnya tingkat pendidikan, minimalnya lahan pertanian, kurangnya keahlian pada masyarakat, serta padatnya penduduk di pedesaan, maka masyarakat pedesaan berusaha untuk merubah kehidupan ekonominya dengan cara berdagang. Kegiatan jual-beli ini diharapkan dapat membantu masyarakat pedesaan dalam memperoleh penghasilan dan mencukupi kebutuhan hidupnya, serta mendorong mereka berhubungan dan berinteraksi dengan dunia luar.

Saat ini masyarakat pedesaan khususnya di kabupaten Maros tidak kalah kemajuannya dengan masyarakat pinggiran kabupaten Maros. Masyarakat desa sekarang sudah banyak membuka usahanya sebagai pedagang, berbagai kegiatan jual-beli dapat ditemukan di pinggiran jalan, dari membuka toko pakaian, toko sepatu, toko sembako, makanan, minuman, dan lain-lain.

Karakteristik Pedagang Kaki Lima di Kabupaten Maros memiliki dualisme pandangan, yaitu positif dan negatif. Di sisi positif, PKL menyediakan peluang kerja bagi penduduk yang tidak terserap sektor formal dengan meningkatnya pengangguran dan pada saat yang sama menyediakan barang dan jasa dengan harga yang terjangkau bagi warga yang kurang mampu. Di sisi negatif, PKL sering menyebabkan kemacetan, merusak wajah kota, terkadang meninimbulkan kejahatan dan ketidaknyamanan sosial lainnya.

Beberapa faktor yang mempengaruhi kinerja PKL yaitu: faktor internal dan eksternal, diantaranya sulitnya mencari lokasi usaha yang sesuai dengan rencana tata ruang dan dukungan pemerintah daerah terhadap penyediaan lokasi usaha PKL masih sangat terbatas. Akibatnya mereka melakukan kegiatan usahanya pada fasilitas-fasilitas umum, seperti badan jalan, trotoar, saluran air, jalur hijau, taman dan sebagainya.

PKL yang memasarkan barang dan jasa merupakan PKL yang paling sering dan banyak ditemukan di setiap daerah. Kehadiran PKL telah menjadi bagian dari gaya hidup masyarakat yang 
membutuhkan barang dan jasa. Setiap pedagang kaki lima, seharusnya memiliki strategi di dalam memasarkan produknya sehingga dapat memperoleh penghasilan lebih banyak lagi. Jumlah pedagang kali lima di Kawasan Kuliner Pantai Tak Berombak (PTB) Kecamatan Turikale Kabupaten Maros, sebanyak 96 pedagang kaki lima, yang terdiri dari berbagai unit usaha, di antaranya: bakso, pangsid, aneka jus, gorengan, sate ayam, sate daging sapi, aneka kue, martabak dan terang bulan, roti bakar serta sarabba.

Berangkat dari fenomena dan data di atas, peneliti tertarik untuk meneliti " Strategi Pedagang Kaki Lima di Kawasan Kuliner Pantai Tak Berombak (PTB) Kecamatan Turikale Kabupaten Maros”.

Berdasarkan latar belakang di atas, maka peneliti dapat merumuskan masalahnya sebagai berikut:

1. Bagaimana karakteristik sosial ekonomi pedagang kaki lima di Kawasan Kuliner Pantai Tak Berombak (PTB) Kecamatan Turikale Kabupaten Maros?

2. Faktor apakah yang berpengaruh terhadap pengembangan usaha di Kawasan Kuliner Pantai Tak Berombak (PTB) Kecamatan Turikale Kabupaten Maros?

3. Bagaimana strategi pengembangan usaha yang dilakukan agar dapat berkembang secara maksimal?

Adapun tujuan yang ingin dicapai dalam penelitian ini adalah:

1. Untuk mengetahui dan menganalisis karakteristik pedagang kaki lima di Kawasan Kuliner Pantai Tak Berombak (PTB) Kecamatan Turikale Kabupaten Maros.
2. Untuk mengetahui dan menganalisis faktor yang berpengaruh terhadap pengembangan usaha di Kawasan Kuliner Pantai Tak Berombak (PTB) Kecamatan Turikale Kabupaten Maros.

3. Untuk mengetahui dan menganalisis strategi pengembangan usaha yang dilakukan agar dapat berkembang secara maksimal.

\section{TINJAUAN PUSTAKA}

Strategi berdagang merupakan salah satu cara atau langkah-langkah yang dilakukan agar mampu mempertahankan kelangsungan hidupnya dalam usaha-usaha yang akan dilakukan salah satunya pada Pedagang Kaki Lima (PKL) di kabupaten Maros.

Dalam strategi berdagang Pedagang Kaki Lima (PKL) dapat dikaitkan dalam beberapa hal antara lain:

a. Modal Sosial

Modal sosial merupakan kekuatan-kekuatan yang muncul dalam diri masyarakat atau kelompokkelompok atau organisasi serta lembaga untuk dapat bersosialisasi dengan masyarakat. serta sesuatu yang dapat menghasilkan Jaringan Sosial (Social Networks), Saling percaya (Trust) dan Hubungan Timbal Balik (Reciprocity).

b. Jaringan Sosial (Social Network)

Jaringan merupakan sekelompok agen-agen individual yang berbagi norma-norma atau nilai-nilai informal yang melampaui nilai-nilai atau normanorma yang penting untuk transaksitransaksi pasar biasa (Fukuyuma 2002: 324). Jaringan sosial terjadi karena adanya keterkaitan (connectedness) antara individu dan komunitas. 
c. Management cara berdagang

Dalam hal ini ada beberapa teknik untuk memulai dengan usaha cara berdagang antara lain:

1) Pemasaran

Pemasaran merupakan sesuatu yang harus dikerjakan dengan membuat sesuatu produk agar tersedianya di tempat usaha, dengan mengatur pajangan (display) dan memelihara penyediaan produk untuk penjualan mendatang atau memahami, menciptakan, mengkomunikasikan, dan memberikan nilai serta kepuasan kepada konsumen.

2) E-commerce

E-commerce merupakan suatu prosedur berdagang atau mekanisme jual beli di internet. Di mana pembeli dan penjual dipertemukan di dunia maya.

3) Loyalitas Pelanggan

Perilaku setelah pembelian suatu produk ditentukan oleh kepuasan atau ketidakpuasan akan suatu produk sebagai akhir dari proses penjualan.

Pengertian PKL dalam pengaturan ini diartikan secara luas, karena tidak hanya bagian jalan/trotoar, tetapi mencakup pula tempat-tempat untuk kepentingan umum yang bukan diperuntukkan tempat usaha serta tempat lain yang bukan miliknya. PKL adalah orang yang dengan modal yang relatif sedikit berusaha bidang produksi dan penjualan barang-barang (jasa-jasa) untuk memenuhi kebutuhan kelompok tertentu di dalam masyarakat, usaha tersebut dilaksanakan pada tempat-tempat yang dianggap strategis dalam suasana lingkungan yang informal (Haryono, 1989).

Faktor internal terdiri dari pengetahuan pedagang dalam menjual dan pelayanan pedagang terhadap pembeli. Faktor eksternal adalah faktor yang mempengaruhi Pedagang Kaki Lima dari luar, terdiri dari faktor lokasi dan faktor Customer Behaviouri (kepribadian).

Hipotesis dalam penelitian ini, adalah:

1. Faktor internal dan eksternal merupakan faktor yang berpengaruh terhadap pengembangan usaha Pedagang Kaki Lima di Kawasan Kuliner Pantai Tak Berombak (PTB) Kecamatan Turikale Kabupaten Maros.

2. Strategi pengembangan usaha yang dilakukan Pedagang Kaki Lima dapat berkembang secara maksimal.

\section{METODE PENELITIAN}

Jenis penelitian yang akan dilakukan ini adalah merupakan penelitian deskriptif kualitatif. Dalam penelitian ini, Peneliti bermaksud mendeskripsikan dan menjelaskan tentang bagaimana karakteristik pedagang kaki lima di Kawasan Kuliner Pantai Tak Berombak (PTB) Kecamatan Turikale Kabupaten Maros; menjelaskan faktor internal dan eksternal terhadap usaha kuliner; dan strategi pengembangan usaha yang dilakukan agar mampu berkembang.

Adapun variabel dalam penelitian ini adalah:

1. Faktor internal adalah faktor dari dalam yang dapat mempengaruhi perkembangan usaha.

a. Pengetahuan adalah penguasaan pengetahuan dalam menjual, yaitu 
menjelaskan manfaat barang yang ia tawarkan kepada pembeli.

b. Pelayanan adalah cara pedagang untuk menanggapi permintaan pembeli dan sikap pedagang terhadap pembeli.

2. Faktor eksternal adalah faktor dari luar yang dapat mempengaruhi perkembangan usaha.

a. Lokasi adalah tempat menawarkan barang dagangan tanpa menghiraukan public space (tempat umum).

b. Customer Behaviour adalah kepribadian yang dimiliki oleh setiap manusia dengan karakteristik yang unik dan berbeda satu sama lain. Hal ini karena kepribadian dapat terkait dengan perilaku konsumen.

3. Strategi pengembangan usaha

a. Modal Sosial adalah kekuatankekuatan yang muncul dalam diri masyarakat atau kelompokkelompok atau organisasi serta lembaga untuk dapat bersosialisasi dengan masyarakat.

b. Jaringan Sosial adalah sekelompok agen-agen individual yang berbagi norma-norma atau nilai-nilai informal yang melampaui nilai-nilai atau normanorma yang penting untuk transaksi-transaksi pasar biasa

c. Manajemen adalah cara memasarkan produk sehingga terjual.

Populasi adalah keseluruhan subjek penelitian. Populasi dalam penelitian ini adalah keseluruhan dari jumlah Pedagang Kaki Lima di Kawasan Kuliner Pantai Tak
Berombak (PTB) Kecamatan Turikale Kabupaten Maros yang berjumlah 96 pengusaha. Peneliti menggunakan sampel jenuh, yaitu sebanyak 96 Pedagang Kaki Lima sebagai sampel.

Pada umumnya dalam analisis ini hanya menghasilkan distribusi frekuensi dan presentasi dari tiap variabel. Misalnya distribusi frekuensi responden berdasarkan: umur, jenis kelamin, tingkat pendidikan dan sebagainya.

Analisis bivariate yang dilakukan terhadap dua variabel yang diduga berhubungan atau berkorelasi. Misalnya jenis kelamin, jenis usaha, tingkat pendidikan, jumlah keluarga, dan asal mula menjadi pedagang terhadap pendapatan kaki lima. Dalam analisis bivariate ini dilakukan analisis proporsi atau presentasi, dengan membandingkan distribusi silang antara dua variabel yang bersangkutan.

\section{HASIL}

Pedagang kaki lima biasanya digunakan untuk penjual yang menggelar lapak di trotoar atau emperan toko. Ternyata istilah pedagang kaki lima karena pedagang itu jualan dengan gerobak roda tiga ditambah dua kaki orang yang mendorong gerobak. Jadi mereka dibilang kaki lima.

Dengan adanya tempat atau ruang yang agak lebar itu kemudian para pedagang mulai banyak menempatkan gerobaknya untuk sekedar beristirahat sambil menunggu adanya para pembeli dagangannya. Seiring perjalanan waktu banyak pedagang yang memanfaatkan lokasi tersebut sebagai tempat untuk berjualan sehingga mengundang para pejalan kaki yang kebetulan lewat untuk 
membeli makanan, minuman sekaligus beristirahat. Berawal dari situ maka Pemerintah Kolinial Belanda menyebut mereka sebagai Pedagang Kaki Lima buah pikiran dari pedagang yang berjualan di area pinggir perlintasan para pejalan kaki atau trotoar yang mempunyai lebar lima kaki.

Seiring perjalanan waktu para pedagang kaki lima ini tetap ada hingga sekarang, namun ironisnya para pedagang ini telah dianggap mengganggu para pengguna jalan karena para pedagang telah memakai ruas jalan dalam menggelar dagangannya. Namun bila menengok kembali pada masa penjajahan Belanda dahulu, antara ruas jalan raya, trotoar dengan jarak dari pemukiman selalu memberikan ruang yang agak lebar sebagai taman maupun untuk resapan air.

Hal ini sangat berbeda dengan sekarang, di mana antara trotoar dengan pemukiman tidak ada jarak sama sekali, pembuatan taman-taman yang ada di sisi pinggir jalan terkesan seadanya, sehingga tidak mampu untuk meresap air apabila hujan. Ini fakta bukan fenomena, ini kenyataan dan bukan rekaan. Lantas tidak sepenuhnya kesalahan itu dialamatkan pada Pedagang Kaki Lima (PKL) yang notabene memang dirasakan sangat mengganggu para pengguna jalan.

Sungguh ironis memang, disatu sisi mereka mencari nafkah, satu sisi mereka juga mengganggu kenyamanan para pengguna jalan. Dalam hal ini pemerintah harus lebih jeli dalam mengambil tindakan dan juga menegakkan peraturan. Lapangan pekerjaan yang sulit juga mendukung maraknya Pedagang Kaki Lima (PKL) yang merupakan alih profesi akibat PHK dan lain sebagainya.

Setelah puluhan tahun berlalu, saat Indonesia sudah merdeka, ruas jalan untuk pedagang kaki itu justru dipakai pedagang untuk berjualan. Kalau dulu namanya pedagang emperan, sekarang disebut pedagang kaki lima. Pada hal jika menurut sejarahnya, mereka seharusnya disebut pedagang kaki lima.

Berdasarkan hasil penelitian yang dilakukan terhadap 96 Pedagang Kaki Lima di Kabupaten Maros, ditemukan kelompok umur pedagang kaki lima antara 31 - 45 tahun ternyata lebih banyak jumlahnya dari pada kelompok umur lainnya.

Jenjang pendidikan Pedagang Kaki Lima didominasi oleh Pedagang Kaki Lima yang berpendidikan SLTA, yakni sebanyak 68 Pedagang Kaki Lima atau sebesar 70,83 persen. Mayoritas Pedagang Kaki Lima adalah laki-laki yang berjumlah 68 Pedagang Kaki Lima atau sebesar 70,83 persen, sedangkan responden perempuan sebanyak 28 Pedagang Kaki Lima atau sebesar 29,17 persen.

Faktor-Faktor yang Berpengaruh Terhadap Pengembangan Usaha di Kawasan Kuliner Pantai Tak Berombak. Kawasan Kuliner Pantai Tak Berombak merupakan salah satu kawasan yang di dalamnya terjadi sangat banyak transaksi jual beli dalam setiap harinya. Para pedagang kaki lima ini harus beroperasi lebih cepat dibandingkan pedagangpedagang yang ada di sekitar kawasan tersebut. Tak heran kalau mereka ada yang sudah mulai beroperasi sekitar jam 16.00 sore. 
Motif atau alasan orang menjadi pedagang kaki lima adalah kebanyakan karena tidak punya tempat usaha, modal yang dimilikinya kecil dan menjadi pedagang kaki lima barang yang dijual lebih cepat laku.

Pedagang kaki lima agar usahanya bisa berkembang dan tetap bisa bertahan, maka mereka harus mendaftarkan dirinya kepada dinas pariwisata yang berada di mana mereka menekuni usahanya.

Pendapatan atau penghasilan Pedagang Kaki Lima umumnya mendapatkan sebesar Rp.500.000 - Rp.1.000.000,- per hari.

Sebanyak 34 orang atau 35,42\% Pedagang Kaki Lima yang menyatakan faktor yang berpengaruh terhadap perkembangan usaha pedagang kaki lima adalah faktor internal, yaitu dengan memiliki pengetahuan dan pelayanan yang baik, artinya dengan memiliki pengetahuan yang cukup dan pelayanan yang baik terhadap konsumen, maka akan memberikan perkembangan usaha pedagang kaki lima.

Sedangkan 30 orang atau 31,25\% Pedagang Kaki Lima menyatakan faktor eksternal, yaitu dengan memiliki lokasi dan kepribadian yang tulus, artinya dengan lokasi yang strategis atau lokasi yang berada di tempat keramaian serta para pedagang kaki lima memiliki kepribadian yang baik akan memperoleh perkembangan usaha.

Selanjutnya dari hasil penelitian diperoleh 32 orang atau 33,33\% Pedagang Kaki Lima menyatakan bahwa faktor kedua poin tersebut. Sebenarnya, bilamana pedagang kaki lima memiliki unsur atau faktor pengetahuan yang tinggi, pelayanan yang baik, dan memiliki lokasi yang strategis serta memiliki kepribadian yang tulus, maka usaha pedagang kaki lima akan meningkat.

Strategi Pedagang Kaki Lima dalam Menjual Barang di Kawasan Kuliner Pantai Tak Berombak.Umumnya Pedagang Kaki Lima menyatakan strategi yang dilakukan sebelum memulai usaha yaitu melakukan survey lokasi terlebih dahulu dan sebagian besar Pedagang Kaki Lima mendapatkan modal dagangan mereka menggunakan modal sendiri.

Sebanyak 18 orang atau $18,75 \%$ Pedagang Kaki Lima menyatakan bahwa dalam berdagang mereka memilih menjual bakso dan pangsid, sedangkan 20 orang atau 20,83 \% Pedagang Kaki Lima menyatakan dalam berdagang mereka memilih menjual aneka jus, sebanyak 12 orang atau 12,50 \% Pedagang Kaki Lima menyatakan bahwa dalam berdagang mereka memilih menjual gorengan, dan 46 orang atau 47,92 \% Pedagang Kaki Lima menyatakan dalam berdagang mereka memilih menjual lainnya (jual sate ayam, sate daging sapi, aneka kue, martabak dan terang bulan, roti bakar serta sarabba).

Sebanyak 40 orang atau 41,67\% Pedagang Kaki Lima menyatakan strategi dalam pengembangan usaha yang dilakukan yaitu dengan memiliki modal sosial, sedangkan 30 orang atau 31,25\% Pedagang Kaki Lima menyatakan strategi dalam pengembangan usaha yang dilakukan yaitu dengan memiliki jaringan sosial, dan 26 orang atau 27,08\% Pedagang Kaki Lima menyatakan strategi dalam pengembangan usaha yang dilakukan yaitu dengan memiliki manajemen yang baik. 


\section{PEMBAHASAN}

Karakteristik Pedagang Kaki Lima menurut umur di Kawasan Kuliner Pantai Tak Berombak (PTB) Kecamatan Turikale Kabupaten Maros didominasi oleh kelompok umur antara 31-45 tahun, sedangkan kelompok umur yang terkecil adalah kelompok umur kurang dari 31 tahun. Karekteristik Pedagang Kaki Lima menurut jenjang pendidikannya didominasi oleh Pedagang Kaki Lima yang berpendidikan SLTA, sedangkan yang berpendidikan sarjana strata satu sebanyak 8 Pedagang Kaki Lima atau sebesar 8,34 persen. Dan karekteristik Pedagang Kaki Lima menurut jenis kelamin yang terbanyak Pedagang Kaki Lima laki-laki.

Menurut para ahli ada dua faktor yang mempengaruhi Pedagang Kaki Lima dalam berusahaa, yaitu faktor internal terdiri dari pengetahuan pedagang dalam menjual dan pelayanan pedagang terhadap pembeli; dan faktor eksternal adalah faktor yang mempengaruhi Pedagang Kaki Lima dari luar, terdiri dari faktor Lokasi dan faktor kepribadian. Berdasarkan hasil penelitian, strategi dalam peningkatan usaha pedagang kaki lima yang dilakukan yaitu dengan memiliki pengetahuan dan pelayanan yang baik, artinya dengan memiliki pengetahuan yang cukup dan pelayanan yang baik terhadap konsumen, maka akan memberikan peningkatan usaha pedagang kaki lima. Sedangkan strategi dalam peningkatan usaha kaki lima yang dilakukan yaitu dengan memiliki lokasi dan kepribadian yang tulus, artinya dengan lokasi yang strategis atau lokasi yang berada di tempat keramaian serta para pedagang kaki lima memiliki kepribadian yang baik akan memperoleh peningkatan usaha.

Dari beberapa jawaban pedagang kaki lima tersebut mengenai kondisi dan eksistensi (keberadaan) pedagang kaki lima di Kawasan Kuliner Pantai Tak Berombak (PTB) Kecamatan Turikale Kabupaten Maros, dilatar belakangi oleh beberapa hal diantaranya yaitu: (a) Tidak punya tempat usaha. (b) Modal kecil. (c) Lebih cepat laku.

Untuk mendapatkan hasil yang maksimal dalam berusaha, harus memiliki pengetahuan dan pelayanan yang memadai, lokasi usaha yang strategis serta para pedagang kaki lima harus memiliki kepribadian yang baik.

Hasil penelitian modal sosial yang paling tinggi, artinya dengan memiliki kekuatan dari diri sendiri para pedagang kaki lima, maka para pedagang kaki lima tersebut berinisiatif untuk melakukan usaha dengan maksud untuk memenuhi kebutuhan primernya, sehingga dapat dijelaskan bahwa usaha yang dilakukan oleh para pedagang kaki lima sebahagian dari unsur modal sosial. Sejalan apa yang tercantum dalam teori yang mengatakan bahwa strategi berdagang Pedagang Kaki Lima (PKL) dapat dikaitkan dalam dengan modal sosial dalam rangka meningkatkan usahanya. Demikian pula jaringan sosial terjadi karena adanya keterkaitan (connectedness) antara individu dan komunitas.

Unsur manajemen merupakan unsur yang tidak dapat dipisahkan dengan kegiatan ekonomi atau kegiatan berusaha, artinya dalam mengembangkan usahanya sebahagian pedagang kaki lima menggunakan manajemen dalam 
menjalankan usahanya. Hanya saja manajemen yang dijalankan sangat sederhana karena pendidikan yang dimilikinya terbatas. Hal tersebut juga dijalankan oleh para pengusaha yang berskala besar, sebab manajemen perusahaan telah memiliki sumber daya manusia yang pengetahuannya lebih baik artinya memiliki karyawan yang berpendidikan tinggi.

\section{PENUTUP}

\section{A. Kesimpulan}

1. Karakteristik Pedagang Kaki Lima menurut umur di Kawasan Kuliner Pantai Tak Berombak (PTB) Kecamatan Turikale Kabupaten Maros didominasi oleh kelompok umur antara 31-45 tahun. Menurut jenjang pendidikannya didominasi oleh Pedagang Kaki Lima yang berpendidikan SLTA. Sedangkan karekteristik Pedagang Kaki Lima menurut jenis kelamin yang terbanyak Pedagang Kaki Lima laki-laki.

2. Faktor internal (pengetahuan dan pelayanan) serta faktor eksternal (lokasi dan kepribadian) merupakan faktor yang berpengaruh terhadap pengembangan usaha Pedagang Kaki Lima di Kawasan Kuliner Pantai Tak Berombak (PTB) Kecamatan Turikale Kabupaten Maros.

3. Strategi pengembangan usaha yang dilakukan Pedagang Kaki Lima dapat berkembang secara maksimal, karena memiliki modal sosial, jaringan sosial dan manajemen.

\section{B. Saran-saran}

1. Kepada Pedagang Kaki Lima (PKL) harus menuruti aturan yang diterapkan oleh pemerintah.

2. Kepada pemerintah, agar selalu memperhatikan kelas bawah seperti pedagang kaki lima yang bekerja dengan menciptakan pekerjaannya sendiri.

3. Kepada masyarakat agar sama-sama menjaga kebersihan, keindahan dan kenyamanan.

\section{DAFTAR PUSTAKA}

Alisjahbana. (2003). Urban Hidden Economy: Peran Tersembunyi Sektor Informal Perkotaan, Lembaga Penelitian ITS, Surabaya. Alma, Buchari. (2009). Kewirausahaan. Bandung: Alfabeta.

Arikunto, Suharsimi. (2011). Prosedur Penelitian: Suatu Pendekatan Praktik. Jakarta: Rineka Cipta.

Bromley, R. (1979). IntroductionThe Urban Informal Sektor: Why Is It Worth Discussing? The Urban Informal Sektor: Critical Perspectives on Employment and Housing Policies. R. Bromley. Oxford: Pergamon Press, 10311032.

Bromley, R. (1979). Organization, Regulation and Exploitation in the SoCalled 'Urban Informal Sektor': The Street Traders of Cali, Colombia. The Urban Informal Sektor: Critical Perspectives on Employment and Housing Policies. R. Bromley. Oxford: Pergamon Press, 1161-1172. 
Damsar. (2009). Pengantar Sosiologi Ekonomi. Jakarta: Kencana.

Echdar, Saban. (2013). Manajemen Entrepreneurship-Kiat Sukses Menjadi Wirausaha.

Jogjakarta: Andi.

Fukuyuma.F. (2002). Trust.

Kebijaksanaan Sosial dan

Penciptaan Kemakmuran. Qalam.

Hart, K. (1991). Sektor Informal.

Urbanisasi, Pengangguran, dan

Sektor Informal di Kota. C. Manning and T. N. Effendi. Jakarta: Yayasan Obor Indonesia, 78-89.

Haryanto, Sindung. (2011). Sosiologi Ekonomi. Yogyakarta: Ar-ruz Media.

Haryono, T. (1989). Faktor-faktor Yng Mempengaruhi Keberhasilan Usaha Pedagang Kaki Lima: Studi Kasus di Kodya Surakarta. Fakultas Pasca Sarjana, Universitas Gajah Mada, Yogjakarta.

Hidayat. (1978). Peranan Sektor Informal Dalam Perekonomian Indonesia dalam Ekonomi Keuangan Indonesia, 26(4).

Hisrich, Robert. D. (2005). Entrepreneurship, Sixth Edition. New York.

Hisrich, Robert. D, Peters, M.P dan Sheperd D.A. (2008). Kewirausahaan Edisi 7, Edisi Bahasa Indonesia. Jakarta: Salemba Empat.

Jumhur. (2015). Model Pengembangan Pedagang Kaki Lima (PKL) Kuliner di Kota Singkawang. Jurnal Ekonomi Bisnis dan
Kewirausahaan 2015, Vol. 4, No. 1, 125-139.

Kasmir. (2011). Kewirausahaan. Cetakan Ke-6. PT. Raja Grafindo Persada. Jakarta.

Kristanto HC, R Heru. (2009). Kewirausahaan

(Entrepreneurship): Pendekatan Manajemen dan Praktik. Yogyakarta: Graha Ilmu.

LB. Ruth Florida W. M. Hutabarat. (2015). Strategi Pengembangan Usaha Kuliner di Kota Malang Berbasis Ekonomi Kreatif. JESP-Vol. 7, No 1 Maret 2015.

Mahmud Machfoedz. (2004). Kewirausahaan Suatu Pendekatan Kontemporer. Yogyakarta : UPP AMP YKPN.

Meredith, Geooffrey G, Et Al. (2005). Kewirausahaan, Teori dan Prektek. Jakarta: PT. Pustaka Binaman Presindo.

Moir, Hazel (1978). Jakarta Informal Sektor. LEKNAS-LIPI, Jakarta.

Nurain, Mujiono, dan Rosmida. (2011). Faktor-Faktor Yang Mempengaruhi Minat Mahasiswa Untuk Berwirausaha (Studi kasus pada mahasiswa program studi admnistrasi bisnis), (di akses dari http: //journal.uad.ac.id, pada tanggal 1 November 2018, Pukul 10:45).

Rachbini dan Hamid. (2006). Ekonomi Informal Perkotaan. PT. Gramedia. Jakarta.

Sethuraman, S. V. (1991). Sektor Informal di Negara Sedang Berkembang. Urbanisasi, Pengangguran, dan Sektor Informal di Kota. C. 
Manning and T. N. Effendi.

Jakarta: Yayasan Obor Indonesia, 90-108.

Sugiyono. (2014). Metode Penelitian

Kuantitatif Kualitatif dan $R \& D$.

Bandung: Alfabeta.

Sunarya, Sudaryono, Saefullah. (2011).

Kewirausahaan. Yogyakarta:

Andi.

Suryana. (2008). Kewirausahaan;

Pedoman Praktis Kiat dan Proses

Menuju Sukses. Jakarta:

Salemba Empat.

Sutamto. (1997). Teknik Menjual Barang.

Balai Aksara. Jakarta.

Tjiptono.Fandy. (2000). Manajemen Jasa.

Yogyakarta. Penerbit Andi

Wibowo, Muladi. (2011). Pembelajaran

Kewirausahaan dan Minat

Wirausahan Lulusan SMK.

Eksplanasi.

Winardi, J. (2002). Motivasi dan Pemotivasian dalam Manajemen. Raja Grafindo Persada. Jakarta.

Wiwin Agustian. (2015). Analisis Faktor

Yang Mempengaruhi Pendapatan

Pedagang Kaki Lima di Seberang

Ulu II Plaju. Jurnal Ilmiah MBiA

Vol.14 No.2, Agustus 2015: 95-

106. 